\title{
A INCOMENSURABILIDADE ENTRE AS FILOSOFIAS E A INEXISTÊNCIA DE REVOLUÇÓES EM FILOSOFIA
}

\section{Alberto Oliva ${ }^{1}$}

As teorias e as escolas se devoram reciprocamente, como os micróbios e os glóbulos, e asseguram por sua luta a continuidade da vida. (Marcel Proust)

Toda teoria, em qualquer campo, só é válida quando nos servimos dela para ultrapassá-la. (André Gide)

RESUMO: Este artigo se ocupa de questôes metafilosóficas. Nele, discutiremos as razôes que fazem com que a filosofia, diferentemente da ciência, problematize a si mesma como empreendimento cognitivo. Em particular, procuraremos identificar como e por que a filosofia acaba se constituindo em problema para si mesma. À exceção das ciências sociais onde há estudos críticos do tipo sociologia da sociologia, a ciência em geral não pốe em discussão a si mesma. Raros são os casos em que a ciência chega ao extremo de questionar a própria cognitividade. A filosofia, em alguns de seus mais lúcidos e profícuos exercícios, não se furta a se avaliar como projeto cognitivo. Com esse tipo de preocupação metafilosófica, nosso artigo questionará a pretensão das grandes filosofias de protagonizar revoluçôes. Defenderemos a tese de que inexistem as revoluçóes postuladas pelos filósofos, destacando que a incomensurabilidade subsistente entre as filosofias não é provocada por rupturas conceituais ou explicativas e sim pela adoção de diferentes pressuposiçóes absolutas, conforme definidas por Collingwood.

PALAVRAS-CHAVE: Essencialismo. Justificaçáo epistêmica. Incomensurabilidade. Progresso cumulativo. Revolução.

\footnotetext{
${ }^{1}$ Professor Associado do Departamento de Filosofia da UFRJ. Coordenador do Centro de Epistemologia e História da Ciência da UFRJ. Pesquisador do CNPq. Autor e tradutor de vários livros de filosofia.
} 


\section{As Revoluçóes Postuladas pelas Filosofias Essencialistas}

Em que pesem as construçóes sibilinas, as confusóes conceituais e as especulações elusivas, a filosofia tem uma história repleta de impecáveis construçôes argumentativas e de luminosos insights. E continua um fecundo laboratório de experimentos mentais e uma indispensável atividade de análise conceitual. O que torna imperioso avaliar a capacidade cognitiva da filosofia é o fato de algumas de suas mais influentes teorias postularem conhecer essências e até chegar à explicação definitiva e à verdade última construindo modelos explicativos impermeáveis a aferiçóes epistêmicas basilares. Do Mundo das Ideias de Platão ao Sein heideggeriano, passando pelo Espírito Absoluto de Hegel, a filosofia incorre manifestamente em hybris explicativa. Nada do que a realidade tem de essencial escapa de suas redes teóricas. Suas oniabrangentes especulaçóes tentam fazer passar por capacidade explicativa o que, muitas vezes, se reduz à engenhosidade de construir universos teóricos autossubsistentes.

A hybris cognitiva, presente principalmente nas filosofias que avançam teses generalistas sobre a Realidade, é gerada pelo descompasso entre o tanto que se pretende explicar e os precários procedimentos epistêmicos empregados para justificar as pretensas verdades e certezas alcançadas. A filosofia se torna ainda mais questionável, como projeto cognitivo, quando se considera apta, por meio apenas do exercício do pensamento puro, a desvelar dimensóes recônditas da realidade ou a apreender determinantes que se ocultam sob as aparências. E merecedora até de condenação ética, quando propóe como conhecimento o que, intrincado exercício de linguagem, nada mais é que pirotecnia verbal. Pior que deixar de se submeter a crivos epistêmicos básicos, a ambição de explicar o Todo, a estrutura última da realidade, peca por elaborar proposiçôes declarativas cujos sujeitos gramaticais carecem de referta. A filosofia está cheia de construçóes argumentativas que exploram a opacidade referencial de suas proposiçóes para criar ilusão de conhecimento.

Desde suas origens pré-socráticas, a filosofia acalenta a pretensão de elaborar por meio do puro exercício da razão Teorias Totais da Realidade. O balanço crítico do "pensamento totalista" mostra o predomínio da inventividade "retórico-linguística” em detrimento da formulação rigorosa de conceitos e da construção de teorias portadoras de efetivo valor explicativo. Guardadas as diferenças, o mesmo pode ser dito das filosofias essencialistas, que sempre rechaçam o ver sob a alegação de que não alcança o Ser. Sustentando que do que se vê nada é o que parece ser, teorizam livremente sobre o Ser sem sofrer qualquer monitoramento, direto ou indireto, das evidências 
empíricas. O senso comum é por elas desqualificado a pretexto de que toma por realidade sua superfície especiosa, de que se prende a um amálgama variável e inconstante de aparências. $\mathrm{O}$ modo como o senso comum lida com a realidade, aferrando-se ao imediatamente dado, o levaria a incorrer em erros sistêmicos de representação da realidade e de conceituação das coisas. Sendo assim, a compreensão do ser envolve inevitavelmente uma depreciação do ver.

A imagem de zênite da racionalidade que a filosofia tem de si mesma é muito bem expressa por Hegel (1955, p. 8), quando afirma que "[...] a história da filosofia descortina a sucessão de nobres espíritos, a galeria dos heróis da razão pensante, que, sustentados pela força dessa razão, souberam penetrar na essência das coisas, da natureza e do espírito, na essência de Deus”. Poucos como Marx (1991, p. 956) tiraram da filosofia a prerrogativa de desvendar essências para entregá-la à ciência: "[...] toda ciência seria supérflua se houvesse coincidência direta entre a aparência e a essência das coisas”. É controverso que essências existam em uma instância ontológica distinta da das aparências. E que possam, caso existam, ser apreendidas. E, mais ainda, que a relevância da filosofia ou da ciência dependa da capacidade de elaborar explicaçóes sobre regióes ontologicamente descontínuas em relação ao que se oferece à observaçáo.

A verdade é que, mesmo sem contar com instrumental metodológico que lhe assegure acesso às essências, a filosofia tem uma história marcada pela denúncia das supostas teias de ilusão em que se enredam as teorias presas ao espetáculo visível e cambiante das coisas. As filosofias essencialistas decretam que nada é como (a)parece ser, nem no mundo exterior dos objetos nem no universo interior dos sujeitos. Chegam ao paroxismo da arrogância cognitiva, quando se consideram capazes de elaborar, desqualificando as teorizações atreladas à dimensão fenomênica, a explicação definitiva sobre a realidade última. Quando crítica, a filosofia não deixa de transformar em um de seus principais problemas o gerado pelo fato de que suas teorias constroem explicaçóes ambiciosas com base em procedimentos de justificação epistemicamente frágeis e questionáveis.

Bradley (2005, p. 1) sintetiza bem o espírito filosófico essencialista/ totalista, quando afirma que

[...] podemos talvez concordar em compreender a metafísica como uma tentativa de conhecer a realidade por oposição à mera aparência ou como o estudo dos primeiros princípios ou das verdades últimas; ou ainda como o esforço de compreender o universo não apenas por partes ou fragmentos, mas como um todo. 
Tendo à frente racionalistas e idealistas, a maioria dos filósofos adota a contraposição entre essência e aparência. Os empiristas e positivistas se destacam entre os poucos que a rechaçam. Ao entenderem que conhecimento nada mais é que senso comum corrigido e metodizado, os empiristas não colocam a filosofia em ruptura com o senso comum.

Resumindo a doutrina positivista, Mill (2005, p. 5) sublinha que o essencialismo é rejeitado com base no pressuposto de que "[...] só temos conhecimento de fenômenos e que nosso conhecimento dos fenômenos é relativo, jamais absoluto". Em termos metafísicos, o positivismo destoa da maioria das filosofias, ao situar o conhecimento possível no plano "do que aparece". O essencialismo persegue o conhecimento absoluto de realidades - ou da Realidade - às quais só se pode ter acesso por meio da imaginação teórica. Para Mill, nem mesmo conhecemos o modo real de produção de qualquer fato, apenas suas relaçóes com outros fatos em termos de sucessão ou similitude. O conhecimento é possível, porque essas relações são constantes, isto é, sempre as mesmas nas mesmas circunstâncias. Para o positivismo, devem ser chamadas de leis as constantes semelhanças que articulam os fenômenos e as constantes sequências que os unem como antecedentes e consequentes: "[...] as leis dos fenômenos são tudo que conhecemos sobre eles - sua natureza essencial e suas causas últimas, sejam eficientes ou finais, nos são desconhecidas e imperscrutáveis". A despeito de muitas de suas críticas ao essencialismo serem procedentes, o positivismo adota uma metafísica fenomenista à luz da qual a ciência se torna a única forma possível de conhecimento. Desse modo, assume uma posição não só antiessencialista, mas também completamente antifilosófica.

Se o conhecimento é de fenômenos, mutáveis e cambiantes, só pode ser setorial e sempre sujeito a passar por revisóes e mudanças derivadas da detecçáo de erros e da novidade ontológica representada pela quebra de uma uniformidade ou regularidade. Não tem a filosofia como produzir conhecimento desse tipo. O progresso que pode buscar não é alcançado pela eliminação de erros com base no recolhimento de novas informaçôes ou na identificação de casos discrepantes dos anteriormente registrados. Se a filosofia deixa de privilegiar o phainomenon - o que aparece - é também porque não tem como dele obter conhecimento. E assim resta à filosofia substantiva, devotada a questóes de primeira ordem, perseguir o conhecimento de essências recônditas ou pelo menos de "realidades" que nem indiretamente se conectam ao (que é) dado. 
Como diferentes filosofias encontram essências as mais variadas, fazendo inventários ontológicos idiossincrásicos, fica inviabilizado o intercâmbio crítico entre elas. Não podendo haver diferentes realidades essenciais, cada filosofia proclama fazer uma revolução, apresentando-se como a única que chega ao que é tal qual é. Dado que a filosofia em seu evolver não alcança uma crescente aproximação das essências, cada filosofia fica refém de suas pressuposições ontológicas particulares. E desse modo as filosofias se tornam incomensuráveis por suas teorias dissentirem sobre o que realmente existe antes mesmo de definirem de que modo as coisas existem. Uma vez que as filosofias concedem o estatuto de essência a entidades, ou dimensões da realidade ontologicamente muito diferentes, ficam todas sujeitas a ter questionada capacidade cognitiva.

As filosofias essencialistas pretenderam demonstrar não apenas que o pensar que se atrela ao que se oferece à observação não chega ao ser, mas que também acaba por velá-lo. Além de apreender de modo falho ou ilusório o que se passa no mundo exterior, a consciência presa às aparências se engana sistematicamente sobre si mesma: encara suas açóes como resultantes de escolhas racionais, quando são determinadas por mecanismos ou causas que ela desconhece. Toma por razão o que não passa de racionalização. Tenta ocultar sua ignorância dos enredos causais, apresentando alegaçóes convenientes como explicaçóes das açóes. Vítima do autoengano, a consciência se vê tomando decisões soberanas, fazendo escolhas livres, sem se dar conta de que decorrem da atuação de forças sobre as quais não tem (cons) ciência nem controle. Com base nesse tipo de esquema metafísico - que contrapóe aparente e real, alegado e determinante - o filósofo se incumbe de descobrir como se formam as ilusóes sistêmicas que toldam o pensar e escravizam o agir.

As teorias filosóficas mais influentes - e as psicológicas e sociológicas delas derivadas - pintam o homem como refém de ilusóes cognitivas e de forças desconhecidas por sua consciência. Além de postularem acesso a essências, essas filosofias ambicionam libertar o homem dos grilhóes materiais e das gaiolas simbólicas. Todas abraçam o pressuposto de que a instância ontológica onde se aninham as forças determinantes não é acessível pela observação ou introspecção. Recusam a camaleônica epiderme visível, alegando contar com um método que respalda a pretensão de suas teorizaçôes de apreender determinantes ocultos. Sem atentar para as dificuldades que precisam enfrentar para se legitimarem como autênticas cogniçóes, acreditam-se capazes de identificar, e até de eliminar, todos os recobrimentos geradores de ilusão - 
naturalmente formados ou artificialmente forjados - para que a realidade se mostre tal qual é.

Ressalta Descartes (1950, p. 48) que, à primeira vista, o sol parece estar perto de nós e, no entanto, está longe. Parece pequeno e é grande. As primeiras impressóes que formamos da Terra mostram que podemos incorrer em erros banais de representação: parece plana, mas é redonda. Parece imóvel, mas gira em torno de si e do sol. A vida social também é geradora de "obviedades" enganosas. Parece marcada pela cooperação, quando é marcadamente conflituosa, ou vice-versa. Várias filosofias se aproveitam da constatação de que muitas (primeiras) impressões são especiosas para defender a permanente contraposição entre a (pretensa) ilusão das teorias presas às aparências e o conhecimento (supostamente) indefectivel das que chegam às essências.

É inegável que falhas nas representações dos objetos, muitas delas decorrentes de informaçóes enganosas supridas pelos sentidos, podem fazer com que em determinadas situaçóes se tome por realidade o que é (mera) aparência. Mas isso não autoriza as Filosofias da Ilusão e da Suspeição a encararem os modos comuns de ver como fadados a acolherem como realidade o que náo passa de casca enganadora. Por mais que a visibilidade na sua crua imediatidade náo revele o que a realidade contém de essencial, disso não se segue que é necessário sempre e in totum rejeitá-la para se chegar ao que é tal qual é.

Ao postular desvendar a realidade última e chegar à explicação definitiva, cada filosofia essencialista se concede o monopólio da cognitividade, sem sequer satisfazer aos requisitos básicos de justificação epistêmica a que deve se submeter toda e qualquer alegaçáo de conhecimento. Se cada filosofia constitui um universo explicativo autossubsistente, com suas teorizaçóes apreendendo o que a realidade tem de essencial, deixa de existir qualquer possibilidade de progresso para a filosofia como disciplina. Inexistindo revisão ou superação, o que cada filosofia define como hoje sabido é o que se sabe para sempre. Nesse caso, o sabido para uma filosofia não tem como ser aprimorado por meio de inovaçôes ou correçóes feitas por outras filosofias. Por isso, cada filosofia essencialista almeja representar, mesmo quando náo o pretenda abertamente, o fim da filosofia.

Como as filosofias desqualificam as metodologias e ontologias uma das outras, não se criam as condições indispensáveis para se chegar a um acordo sobre o que em cada uma é efetivamente inovador. $\mathrm{O}$ estatuto revolucionário postulado por uma não é reconhecido pelas demais. $\mathrm{O}$ resultado final é a 
depreciação das pretensôes explicativas, revolucionárias ou não, de todas. Se as filosofias fossem julgadas por parâmetros de avaliação compartilhados, não faria sentido cada uma se considerar protagonizando uma revolução conceitual e/ou explicativa que as demais deixam de assim enxergar. A despeito de suas conhecidas inovaçóes conceituais, a filosofia não abriga as tantas revoluçóes explicativas alardeadas. Se fossem revolucionárias todas as filosofias que pretenderam sê-lo, no mínimo se teria uma trivialização do fato revolucionário, a ponto de deixar de poder ser entendido como mudanças radicais caracterizadas pela derrocada de uma "ordem explicativa" e a entronização de outra.

Inexistindo em filosofia "ordens intelectuais" consensualmente endossadas e grandes mudanças teóricas universalmente acolhidas, fica difícil determinar o que de genuinamente revolucionário podem conter as descontinuidades explicativas, as reformulaçóes conceituais e os remapeamentos ontológicos. Para que irrompa uma revolução é necessário, tanto em ciência quanto em filosofia, que exista um modo hegemônico de ver e explicar as coisas. Desde os pré-socráticos, a proliferação de teorias tem sido a tônica. Não há um status quo filosófico - estipulador, entre outras coisas, de critérios rigidamente definidores das soluçóes aceitáveis para os problemas - contra o qual possa ocorrer uma revolução. Já que não é possível comprovar de forma epistemicamente fundamentada de que modo uma filosofia é explicativamente superior a outra(s), cada filosofia recorre à saída cômoda, porém artificial, de se caracterizar como revolucionária.

Os grandes filósofos se dizem introdutores de grandes transformaçôes teóricas como forma de contornarem o fato de que praticamente inexiste avanço substantivo - e não apenas conceitual - universalmente absorvido na história da filosofia. As pretensas revoluçóes desviam a atenção dos milenares e insanáveis conflitos filosóficos que impedem a transmissão canônica - como a propiciada pela rígida educação ministrada nas ciências maduras - dos conteúdos fundamentais do conhecimento filosófico. Observa Hegel (1955, p. 21) que, “[...] diante do espetáculo de tão múltiplas opiniôes, de tão numerosos e diversos sistemas filosóficos, a pessoa se sente arrastada pela confusão, sem encontrar um ponto firme com o apoio do qual possa dela se desvencilhar".

As filosofias recorrem sem parcimônia à retórica da revolução, por questionarem os fundamentos umas das outras, sem terem como objetivamente superar suas divergências. Deixam de lado o desafio de que precisam ser comparáveis para que uma delas possa justificadamente decretar sua superioridade frente às demais. Enquanto nas ciências maduras são 
raríssimas as revoluçóes, e não são seus autores que assim as qualificam, na filosofia são costumeiramente reivindicadas e o são pelos que alardeiam produzi-las e pelos que aderem a elas. Guinadas que impactam apenas uma tradição de pensamento, mas não a filosofia como um todo, não merecem ser destacadas como revolucionárias. Como cada filosofia se vê obrigada a lidar com os fundamentos da filosofia em geral, e não apenas com o de suas teorias, é compreensível que deseje que as mudanças que propóe sejam encaradas como radicais, como afetando tanto o conhecimento filosófico até então amealhado quanto a própria natureza da filosofia. O problema é que a aferição de êxito desse tipo de empreitada é sempre interna a cada filosofia.

Contraria a pretensão revolucionária de várias filosofias o fato de, na história da filosofia, a polêmica ser endêmica e envolver divergências insuperáveis em torno de formulaçôes conceituais, pressuposições ontológicas, fundamentos epistêmicos e quadros axiológicos. A falta de consenso e a ilusão de revolução talvez justifiquem a dura avaliação de Austin (1970, p. 175): “[...] a filosofia tem sido por tanto tempo estéril carecendo da alegria da descoberta, dos prazeres da cooperação e da satisfação de se alcançar a concordância”. Pouco contribui para lidar com o desafio de como conferir cognitividade à filosofia propor, como Russell (1959, p. 7), que "[...] o único modo de descobrir o que é filosofia é fazer filosofia”. Se nem mesmo uma ação é justificada por ser simplesmente feita, não pode a filosofia, que ergue pretensóes de verdade para suas asserçôes, ser simplesmente praticada.

O que muitos filósofos estatuíram como condição necessária e suficiente para se ter conhecimento - ser a crença verdadeira e justificada - não tem como ser satisfeita nem por suas próprias filosofias. Se a definição de conhecimento proposta ao final do Teeteto fosse aplicada à filosofia, pouquíssimas de suas teorias poderiam se candidatar a ser conhecimento. Em qualquer domínio do saber, é dificílimo chegar a crenças que possam ser comprovadas verdadeiras e ser impecavelmente justificadas. E mais ainda em filosofia. E ainda mais quando a filosofia ambiciona fazer revoluçóes que demandam novas verdades assentadas em diferentes formas de justificação epistêmica. Sendo as proposições filosóficas declarativas, deveria ser possível especificar valores-deverdade para elas. E se inexiste a possibilidade de se estabelecer a verdade, ou ao menos a crescente e gradual confirmação das proposiçóes, não há como dar início ao processo que visa à sua justificação epistêmica.

A maioria das filosofias cria a ilusão de revolução, atacando as estruturas e fundamentos das vertentes de pensamento mais aceitas ou mais prestigiosas. 
Umas poucas se pretendem revolucionárias, condenando a filosofia como um todo, como projeto cognitivo. Mas há também as filosofias que curiosamente defendem uma concepção tão restritiva de conhecimento que nem elas mesmas têm como passar por seus crivos epistêmicos. Ao decretar que se lance às chamas o que não é raciocínio formal ou experimental, Hume (1952, p. 509) exemplifica como a defesa de uma concepção de conhecimento pode impedir de ser conhecimento a própria filosofia que a propóe. No último aforismo do Tractatus Logico-Philosophicus, Wittgenstein reconhece estar sua filosofia sujeita à autodesqualificação, caso os critérios de avaliação que ela enuncia sejam a ela mesma aplicados. Tenta contornar isso, recorrendo à metáfora sibilina de que "[...] é preciso jogar fora a escada depois de ter por ela subido" $(1971,6.54)$.

Sublinha Dummett (2010, p. 11) ser estéril indagar se a filosofia é sobre a realidade, sobre os conceitos por meio dos quais a pensamos ou sobre os meios linguísticos que usamos para expressar os conceitos: "[...] ela diz respeito à nossa visão da realidade e busca clarificar os conceitos por meio dos quais a concebemos e, por conseguinte, as expressóes lingüísticas através das quais formulamos nossa concepção". Registre-se, no entanto, que faz toda diferença saber se a revoluçáo reivindicada por uma filosofia se dá no plano dos conceitos, dos meios linguísticos ou do acesso a partes antes inalcançadas da realidade. Em filosofia, as genuínas inovaçóes conceituais são pouco frequentes, mas ocorrem. Já as mudanças explicativas radicais, que envolvem a substituição de teorias de primeira ordem, são o tempo todo postuladas sem que seus proponentes comprovem que elas possuem efetivo caráter revolucionário.

Confrontados com as explicaçôes da ciência moderna, alguns pensadores passaram a se interrogar a que tipo de atividade cognitiva pode a filosofia se devotar. Locke (1952, p. 89) atribuiu missão modesta e subalterna ao filósofo. Fez isso depois de sublinhar que "[...] nem todos devem esperar ser um Boyle, um Sydenham numa época que se destaca por produzir mestres da grandeza de Huygenius e do incomparável Newton". Subordinando a filosofia à ciência, proclama que "[...] é ambição na medida certa ser empregado como servente ao qual se dá a incumbência de limpar um pouco o terreno de modo a remover parte do entulho que se coloca no caminho do conhecimento" (1952, p. 89). Aceita tal visão, a filosofia se reduz a uma atividade devotada à remoção dos entraves à cognição e à formulação de questóes de segunda ordem, de natureza eminentemente conceitual. 
É fato que no passado algumas das grandes obras filosóficas foram fomentadas pela ciência. A tese de que o avanço da filosofia depende da ciência se aplica a um número expressivo de autores e períodos da história da filosofia. Desde o alvorecer da filosofia grega, pensadores representativos buscam fertilizar suas ideias com o adubo do conhecimento extrafilosófico. Abeberam-se tanto do tipo formal de conhecimento provido pela matemática quanto do conhecimento de tipo factual fornecido pelas ciências empíricas. Althusser (1976, p. 45) exagera, ao sustentar que "[...] é uma lei: a filosofia está sempre ligada às ciências". Repetindo a tese de Piaget (1968, p. 67-8) da dependência da filosofia à ciência, Althusser advoga de modo reducionista que a filosofia nasceu com Platão com a abertura do continente-Matemática, foi transformada por Descartes pela abertura do continente-Física e revolucionada pela abertura do continente-História por Marx. É questionável que as grandes transformações da filosofia sempre foram cientificamente induzidas. E, se tivessem sido, a filosofia não teria uma história própria, seria apenas um tipo de investigação a reboque do científico. Criaria apenas visóes de mundo sobre resultados científicos setoriais. Pela óptica simplista de Althusser, a filosofia, desprovida de dinâmica própria, só sofreu essas três grandes mudanças.

Fazem parte de uma minoria os que apregoam que a filosofia é uma continuação da ciência por outros meios - conceituais - e que a caracterizam como a parte mais abstrata da ciência. Quine (1969, p. 82-3) integra essa minoria, quando dá à filosofia a incumbência de incorporar as descobertas das ciências para poder se credenciar a elaborar uma teoria naturalizada do conhecimento e da mente. Assim concebida, a filosofia é ancila da ciência e nada pode produzir de intrinsecamente revolucionário. Diferente é a proposta de cientificizar a filosofia, feita por Russell (1977, p. 122), quando defende uma "filosofia científica, gradual e experimental como as outras ciências", capaz de “inventar hipóteses suscetíveis de correção". É questionável que se possa lidar com os problemas clássicos da filosofia, imitando os procedimentos consagrados das ciências formais ou empíricas. Caso se pudesse, esses problemas precisariam passar por uma reformulação que acabaria por lhes retirar justamente o que os singulariza. No fundo, a filosofia teria de abandonar a maioria de seus problemas tradicionais, já que, para eles, não se tem como viabilizar uma abordagem científica e muito menos uma cientificização das respostas.

Moore (1952, p. 14) sustenta posição peculiar sobre a gênese dos problemas filosóficos e os modos de enfrentá-los: “[...] não penso que o mundo ou as ciências me tenham sugerido qualquer problema filosófico. O que me 
sugeriu problemas filosóficos foram as coisas que outros filósofos disseram sobre o mundo ou as ciências". Por essa visão, o filosofar não é desencadeado pelo maravilhamento diante do grandioso espetáculo do mundo nem propelido pelas conquistas explicativas da ciência. Moore se diz interessado principalmente em dois tipos de problema: "[...] o de tentar elucidar o que determinado filósofo queria dizer com algo que afirmou e determinar se havia razóes satisfatórias para supor que o que disse era verdadeiro ou falso". Por essa óptica, o filósofo se devota a dissecar as construçóes de outros filósofos com a preocupação precípua de aferir as razóes que invocam para defendê-las. Mas mesmo o filósofo que procura identificar com base em que outro pensador supóe conquistar determinadas verdades não pode deixar de reconhecer que a filosofia, independentemente de como é praticada, se mostra quase sempre impotente para definir os conteúdos de verdade e de falsidade de suas teorias.

Estando a ciência voltada para o estudo do que é (há), pode-se encarregar a filosofia de examinar e problematizar as condiçôes que tornam possivel o que (é) há. Existiriam, assim, dois domínios claramente definidos: o "reino dos fatos", a cargo da ciência, e o das condiçôes de possibilidade, sob a jurisdição da filosofia. O problema é que a filosofia cria conflitantes teorias, mesmo quando se propóe a determinar, por exemplo, como é o conhecimento possível. Por mais que existam vários fatores viabilizando a existência de algo, não se justifica a indefinida subsistência de visóes excludentes sobre ele. E muito menos que uma dessas visôes, sem promover a efetiva superação das teses defendidas pelas demais, conceda a si mesma o estatuto de revolucionária.

Por juntar nebulosidade conceitual com inoperância explicativa, parte significativa da filosofia está sujeita a ser acusada de gerar ilusão cognitiva. Em alguns casos, merece até ser depreciada como ilusão linguística. A completa desqualificação da filosofia como projeto cognitivo se baseia no diagnóstico de que suas proposições são subprodutos da sintaxe logicamente frouxa das línguas naturais. E se suas proposiçóes são declarativas sem ter como receber valores-de-verdade, a filosofia é, de acordo com a taxonomia de Aristóteles (1952a, p. 26), um logos semantikos. Podem suas proposiçóes ser entendidas sem que se consiga qualificá-las de verdadeiras ou falsas, como seria possível se constituíssem um logos apophantikos. A acusação de que as proposiçóes filosóficas sequer logram produzir sentido reduz a filosofia a ilusionismo linguístico. E se as proposiçóes filosóficas carecem de sentido, nada acrescenta desqualificá-las pelo fato de serem declarativas e não se poder a elas assinalar valores-de-verdade. 
Warnock (1957, p. 138) sublinha que na metafísica são mais aparentes que reais as diferenças entre as teorizaçóes. Se a asserção metafísica sustenta, por exemplo, que "tudo ocorre em consonância com os propósitos de Deus", isso implica que não há e nem poderia haver eventos ocorrendo sem estarem em conformidade com os desígnios divinos. Mas, sendo assim, nada que ocorra pode contar contra a asserção ou a seu favor. Não faz por isso diferença, salienta Warnock, se a asserção é afirmada ou negada. Não são genuínas as polêmicas travadas no campo da razão pura se não há forma de julgar e superar as divergências. Por isso, observa Kant (1952, p. 20): “[...] as inevitáveis contradiçôes da razão consigo mesma tem desde muito tempo arruinado a reputaçáo de todo sistema metafísico". Cria dificuldades para a defesa da cognitividade da metafísica o fato de suas proposiçôes serem sintéticas - no sentido de que os princípios da lógica não são suficientes para determinar sua verdade - se mostrando impermeáveis a crivo empírico. Sem contraexemplos que derrubem teorias consagradas, a revoluçáo pode, quando muito, ser conceitual.

A apreciação de Reichenbach (1954, p. 9) - "[...] a filosofia tem sido o tempo todo prejudicada por uma confusão lógica com a poesia, da explicação racional com a fantasia, da generalidade com a analogia” - é generalista e não faz justiça aos melhores momentos da reflexão filosófica. Ademais, sua crítica de que "[...] os inúmeros sistemas filosóficos são como a Bíblia, uma obraprima poética, abundantes em imagens que estimulam nossa imaginação, mas desprovidos do poder de clarificação que brota da explicação científica" - se enfraquece por julgar a filosofia tomando a ciência como modelo. Não se justifica desmerecer a filosofia por ser incapaz de produzir conhecimento como o científico. Por mais que possa ser questionada como empreendimento cognitivo, é inapropriado julgar a filosofia com as lentes da ciência. Ainda que se pretenda respaldado na ciência, o cientismo não passa de uma antifilosofia que, filosoficamente avaliada, se revela artificialmente restritiva, ao desqualificar problemas simplesmente por não serem suscetíveis de tratamento científico.

Depois de asserir que "[...] a totalidade das proposições verdadeiras é a ciência natural total”, Wittgenstein (1971, 4.11 e 6.53) proclama que

[...] o verdadeiro método da filosofia seria: nada dizer a não ser o que pode ser dito, isto é, as proposiçóes da ciência natural, ou seja, algo que nada tem a ver com filosofia e a partir disso sempre demonstrar, quando alguém deseja dizer-nos algo metafísico, que não confere significado a alguns signos em suas proposiçôes. 
Reduzir o conhecimento possível às ciências naturais, concedendo-lhes o monopólio de alcançar verdades, impede não apenas a filosofia de postular valor cognitivo, mas também as ciências humanas e sociais.

Contra esse naturalismo, cabe observar que a história das disputas metacientíficas ao longo do século passado mostra que nenhuma compreensão das ciências naturais, nenhuma concepção de "método científico" alcançou ampla aceitação. Ademais, é discutível que as proposiçôes das ciências naturais, sustentadas por determinada quantidade de evidência empírica, possam ser qualificadas de verdadeiras e que esgotem o conjunto das verdades contingentes possíveis. Há, na tese de Wittgenstein, um tácito dualismo de tipo platônico: a episteme das ciências naturais - produtora de verdades - e o reino das opinióes (a procissão de doxai) sobre os demais assuntos, principalmente os humanos.

Comparar a filosofia com a ciência, cobrando da primeira um tipo de cognitividade que só se faz presente na segunda, só seria adequado se ambas tratassem dos mesmos tipos de questão, com as mesmas metodologias. Como não é isso que ocorre, seus procedimentos e resultados não podem ser julgados pelos mesmos critérios. $\mathrm{O}$ valor cognitivo da filosofia precisa ser intrinsecamente determinado, aferindo-se se chega ou não aos resultados explicativos pretendidos, e não por sua proximidade ou afastamento da ciência. Não se justifica por isso caracterizar, à maneira de Carnap (1937, p. 278), "[...] as pretensas sentenças da metafísica, da filosofia dos valores, da ética [...] como pseudocientificas”. Igualmente criticável, mas mais defensável, é sua avaliação de que "[...] não têm conteúdo lógico, são apenas expressóes de sentimentos que, por seu turno, estimulam sentimentos e tendências volitivas nos ouvintes".

As restrições mais importantes que podem ser feitas à filosofia são de natureza filosófica. Mesmo quando o filósofo invoca a ciência como exemplificação do conhecimento genuíno, não se reporta à ciência tal qual praticada, mas à ciência como é por ele filosoficamente reconstruída. Isto é muito bem exemplificado pelo empirismo lógico, quando elabora uma metaciência idealizada - em que a ciência é conceitualmente reconstruída from the bottom up - e a ela recorre para dar sustentação a suas teses antifilosóficas. A ciência não se pronuncia sobre a filosofia. Normalmente, são filósofos que a invocam contra a filosofia. Quando muito, o cientista repele como inapropriadas, como fazem Sokal e Bricmont (1999), as apropriaçóes que os filósofos fazem dos conceitos e teorias científicos. 
Parte significativa da filosofia substantiva merece ser acusada de produzir ilusão explicativa "linguisticamente" fomentada. Suas teorias não têm como possuir importe cognitivo simplesmente porque os sujeitos gramaticais de seus enunciados carecem de referta, tanto no mundo das aparências quanto no das essências. $\mathrm{Na}$ realidade, não fazem referência ao que quer que seja. Mais que desqualificar a filosofia como ilusão cognitiva, Wittgenstein, no Tractatus Logico-Philosophicus, a acusa de ilusão linguística, de ser incapaz até de conferir sentido a suas proposiçóes. A terapia proposta por Wittgenstein (1971, 4003) consiste na eliminação lógico-linguística da maioria dos problemas da filosofia, tendo em vista que "[...] a maioria das proposiçóes e questóes sobre temas filosóficos não é falsa, mas absurda”. E completa: “[...] não podemos, portanto, responder a questóes desse tipo, apenas enunciar sua falta de sentido". Sendo assim, os contrassensos produzidos pela filosofia substantiva resultariam de não se compreender, independentemente dos fatores psicossociais que os motivam, a lógica de nossa linguagem e da tentativa de ir além dos limites ao pensar (à expressão do pensamento) traçados no interior da linguagem. Nesse caso, em toda a história da filosofia só ocorreria uma revolução - a que faz esse diagnóstico. E ela representaria o fim da filosofia, se fosse reconhecida como tal pelas diferentes escolas de pensamento.

A avaliação lógico-epistêmica da filosofia - e até da ciência - se faz com as lentes de uma de suas tradiçôes de pensamento. Mesmo a crítica sintáticosemântica - a que indigita os modos logicamente frouxos com que a filosofia constrói suas teorias de primeira ordem e a que aponta para a tendência da filosofia a elaborar proposiçóes declarativas incapazes de fazer referência a estados de coisas - é essencialmente de natureza filosófica. Nenhum domínio científico se dedica a fazer esse tipo de avaliação da filosofia. É uma filosofia que decreta que a filosofia é produto de usos logicamente condenáveis das línguas naturais. É uma filosofia que vê a credibilidade cognitiva da filosofia abalada por elaborar teorias que, devidamente dissecadas, exibem vazio descritivo e inoperância explicativa. É também uma filosofia que denuncia as teorizaçóes filosóficas que tentam disfarçar confusôes conceituais, argumentaçóes abstrusas e ininteligibilidades pomposas com retórica altissonante. Por isso, Aristóteles, no Protréptico (Fragmento 2), parte da disjunção "[...] ou se deve filosofar ou não se deve" para chegar à conclusão da indispensabilidade da atividade filosófica: "[...] caso se deva filosofar é preciso filosofar e caso não se deva, também é necessário filosofar". Isso significa que não se evita o filosofar, mesmo quando se faz uma avaliação que o condena. 
Popper (1978, p. 187-8) dá a impressão de pretender conceder valor cognitivo à filosofia, quando advoga que os insights metafísico-filosóficos têm eventualmente o poder heurístico de sugerir caminhos para a pesquisa empírica. Podem, em alguns casos, passar por transformaçóes que os tornem componentes de teorias testáveis. Mesmo não tendo valor cognitivo intrínseco, podem estar na origem do que tem. Ainda que tencionando enunciar uma tese antipositivista, Popper atribui à filosofia a função subserviente de fornecer material ideacional passível de ser, via reprocessamento, aproveitado pela ciência. As teorias refutáveis, as únicas que podem aspirar a ser conhecimento, não são produzidas pela filosofia. A noção metafísica contribui para a produção do conhecimento, quando passa por transformaçóes sintático-semânticas que a transmutam em conceito capaz de integrar uma teoria - científica - com valor cognitivo. $\mathrm{Na}$ discussão da cognitividade da filosofia, não reconforta o fato de seus lampejos poderem ser reprocessados pela ciência, de modo a se tornarem conceitos de teorias testáveis.

A admissão de Popper (1972, p. 16) de que há um método que poderia ser chamado de "método da filosofia" se torna igualmente decepcionante, por ser seguida da ressalva de que não é característico da filosofia; que é o método de toda discussáo racional e se aplica tanto às ciências naturais como à filosofia. E assim o formula: "[...] enunciar claramente o problema e examinar criticamente as várias soluçóes propostas”. Criar livremente conjecturas e tentar refutá-las de todos os modos possíveis e concebíveis é, para Popper, o que de essencial incumbe ao cientista fazer. Em razão de as proposiçôes filosóficas não serem refutáveis, o filósofo não tem como seguir essa recomendação. Daí a proposta popperiana de estender uma versão genérica desse método - "[...] enunciar claramente o problema e examinar criticamente as possibilidades de solução" - à filosofia. Mas, como esse "método crítico" se aplica a praticamente todas as áreas do saber, não tem como ser invocado para caracterizar a singularidade epistemológica da filosofia. Tendo em vista que por "método crítico" as filosofias entendem procedimentos bem diferentes, sua adoção não constitui uma resposta eficiente para o desafio de como demonstrar a superioridade de uma teoria filosófica para a qual há alternativas explicativas disponíveis.

Parte expressiva da filosofia contemporânea, genericamente rotulável de analítica, só vislumbra uma atividade capaz de conferir valor cognitivo ao filosofar: a de enfrentar questóes de segunda ordem, isto é, possuidoras de natureza essencialmente conceitual. $\mathrm{O}$ confinamento à análise conceitual levaria a filosofia a renunciar a forjar teorias substantivas votadas a explicar 
realidades ou até a Realidade. Atendo-se aos conceitos, e à sua elucidação, a filosofia afastaria a tentação do puro exercício retórico e a do mero posicionamento ideológico. Renunciando a lidar com conteúdos, a elaborar doutrinas ou sistemas, tudo que a filosofia tem a oferecer em termos cognitivos é fruto da análise lógico-linguística.

Se a definição de Dummett (1993, p. 4-5) de filosofia analítica - "[...] baseada na visão de que a análise do pensamento deve ser feita pela análise da linguagem" - tivesse predominado na história da filosofia, as teorias filosóficas não passariam de três ou quatro. Sem dispor de laboratórios, sem ter como realizar experimentos, fontes primárias a buscar e comprovaçóes a estabelecer, os filósofos podem se incumbir de construir e examinar conceitos. Mas obrigar a filosofia a ser uma atividade confinada ao enfrentamento de questóes de segunda ordem envolve fazê-la renunciar aos problemas que historicamente têm sido decisivos, na construção de sua identidade. Além do mais, não se pode deixar de concordar com Williamson (2007, p. 3), quando assinala que "[...] poucas questôes filosóficas são questôes conceituais em qualquer sentido distintivo, a não ser quando os filósofos optam por formular questôes sobre conceitos".

Defendemos a tese de que, em filosofia, os "conflitos de interpretação" derivam da escolha do que Collingwood (2007, p. 32) chama de pressuposiçóes absolutas. Estas não são verificáveis, se o fossem seriam relativas, e não é possível distingui-las como verdadeiras ou falsas. Apesar de não darem respostas, encaminham tipos de resposta. São elas que definem como ver a realidade, como a ela se dirigir, o que nela buscar e a escolha da modalidade de teoria por meio da qual se procura organizar e hierarquizar o que no campo possível de observáveis se considera fato ou ocorrência. Mesmo sem gerar conhecimento, as pressuposiçóes absolutas definem diferentes modos de acessar a realidade. Cada conjunto de pressuposiçóes absolutas leva a uma forma de classificar e problematizar o que ocorre no mundo. As diferentes pressuposiçóes absolutas adotadas pelas várias filosofias as levam a optarem por discrepantes requisitos epistêmicos e a fazerem excludentes inventários ontológicos. Não sendo possível estabelecer os méritos relativos de cada uma, subsiste incomensurabilidade entre elas.

Se a identidade essencial de uma filosofia é formada por pressuposiçôes absolutas que não são compartilhadas com as demais, deixa de ser possível compará-las objetivamente. Tenha-se, no entanto, presente que uma filosofia cria seu território ontológico e define o que se vai nele buscar conhecer, e de que modo, mesmo que com seu "método particular", a nenhum conhecimento 
chegue. Ainda que fracasse em produzir conhecimento substantivo, a filosofia é a grande supridora dos esquemas de representação com base nos quais são definidas formas variadas de abordar a realidade e de categorizar o que nela existe e ocorre. Mesmo passando ao largo do registro dos conteúdos que se oferecem à observação, a filosofia se arvora a caracterizar ontologicamente a empeiria estatuindo, entre outras coisas, se é a fonte do conhecimento genuíno ou apenas o domínio das aparências enganosas sobre o qual só se consegue ter opiniốes descartáveis. Como não dá para defender esta ou aquela forma de acesso à realidade - por exemplo, realista ou idealista, empirista ou racionalista recorrendo apenas a proposições empiricamente comprováveis, pode-se chamar de "filosófico" o esquema ideacional que constrói um tipo de organização explicativa para os fatos dispersos e fragmentários que constituem o mundo.

Optar pela pressuposição absoluta que reduz a realidade ao conjunto de suas aparências ou, a contrario sensu, pela que a identifica com essências recônditas por si só não é conhecimento. Mas define que tipo de conhecimento, independentemente de se conquistável ou não, buscar. Reféns de pressuposiçóes absolutas, as filosofias apresentam as contraposições que vão engendrando, ou as guinadas que propóem nos modos de abordagem, como revoluçôes. Apresentam como revolucionário o que sequer tem como objetivamente comprovar sua superioridade explicativa.

De modo simplificador, podemos dizer que as filosofias essencialistas se associam às seguintes pressuposiçôes absolutas: 1) subsiste uma rígida separação entre episteme (conhecimento demonstrativamente certo) e doxai (impressóes circunstanciais), de tal forma que só pode haver conhecimento sobre os constituintes invariantes e últimos da realidade, jamais sobre cambiantes estados de coisas; 2) a realidade, no que tem de essencial, existe de um modo completamente diferente daquilo que se revela na sua imediatidade; 3) diferentemente das causas, as razóes alegadas pela consciência para o que faz e pensa são racionalizações; 4) a verdade, que resulta da correspondência entre o que se diz e o que é, é definitiva, representa a apreensão das coisas sub species aeternitatis; 5) o conhecimento é insuscetível de revisão, nada deve a variáveis idiossincrásicas ou contextuais, e a justificação provida para ele é infalibilista.

É claro que cada uma das filosofias que perfilham a maioria dessas pressuposiçóes absolutas se vê realizando a única revolução possível, uma vez que acredita que o conhecimento genuíno começa e termina com ela. Estando uma dessas filosofias certa, o processo de (re)formulações teórico-conceituais não tem por que prosseguir. Chegar a uma explicação definitiva da realidade 
torna também desnecessário o domínio do saber que a alcança. Se uma filosofia supóe ter chegado à Verdade, tem a ambição, ainda que velada, de decretar o fim da Filosofia. Mais que introduzir profundas mudanças explicativas ou conceituais, fazer revolução, nesse caso, representa o fim da história do pensamento, e não apenas de determinada linha de pensamento, porque não há avanço a ser obtido depois dela.

Já as filosofias relativistas costumam adotar as seguintes pressuposiçôes absolutas: 1) todo tipo de apreensão do que se passa no mundo varia de pessoa para pessoa, de grupo para grupo ou de classe para classe; 2) todo tipo de conteúdo intelectual, se não for subjetivo, é fruto de construção social; 3) o valor de uma explicação é definido pelo que se pode variavelmente fazer com ela; 4) a verdade resulta do consenso entre as consciências; 5) o significado é fruto do uso contextualizado das palavras; 6) a linguagem não tem como ser transcendida, não há como postular sua correspondência com uma dimensão extralinguística: modos de dizer determinam o que se apreende como modos de ser.

Teses relativistas parecidas com as supracitadas têm sido formuladas desde os sofistas. Versóes adaptadas têm sido defendidas também por sociólogos e antropólogos contemporâneos. Rorty (1994, p. 127) propóe que as crenças sejam tratadas como hábitos de ação, e não como representações, e as descriçôes da realidade como dependentes dos propósitos visados nos processos de interação entre pessoas e entre estas e o mundo. Segundo essa óptica, as linguagens, mesmo quando utilizadas com objetivo cognitivo, são ferramentas que constroem o que existe, e não meios de expressão obrigados a espelhar as realidades estudadas. Se a filosofia não precisa prestar contas ao que é, em seu seio não ocorrem revoluçôes conteudísticas. Tenha-se em vista, contudo, que apesar da natureza puramente "linguística", as grandes mudanças nos modos filosóficos de ver o mundo têm o potencial, destacado por Rorty, de afetar a ação humana.

O criacionismo linguístico, para a qual o que se apreende do mundo é subproduto da linguagem, é assim enunciado por Heidegger (2000, p. 15): "[...] é na palavra, na linguagem, que as coisas primeiramente vêm a ser e são". As filosofias que atribuem à linguagem o poder de determinar o que são os fatos identificam o que pode ser conhecido com o que pode ser dito. Opóemse à visão tradicional que entendia que escravizar a linguagem à expressão de estados de coisas é precondição para o conhecimento. As teorias especulativas que se avaliam apenas internamente, que se mostram impermeáveis a crivos extrateoréticos, absolutizam comodamente o dizer para não precisarem 
submetê-lo ao ser. Mas, se a mudança se reduz à introdução de novos modos de dizer, sem sequer chegar ao plano conceitual, a revolução filosófica pretendida não passa de retórica.

\section{QUe ReVOluÇóes a filosofia faz COM SEUS PROBlemas?}

São nítidas as divergências entre as filosofias, quando se trata de definir que problemas destacar e que soluçóes acatar. São discordâncias - conceituais ou substantivas - quanto à natureza dos problemas, ao método capaz de enfrentálos, à possibilidade de solvê-los e ao que se deve considerar uma efetiva solução. $\mathrm{O}$ fato de para cada problema filosófico existirem inúmeras teorias, contrárias ou contraditórias, não geraria indecidibilidade epistêmica, se as principais diferenças entre as filosofias pudessem ser objetivamente arbitradas. Prevalecendo a sobrevivência sem seleção, a indefinida coexistência dos contrários, o impasse entre ismos que se entredevoram, a filosofia não tem como postular avanços entendidos como crescente poder de solver problemas. Por não serem julgadas pela capacidade de resolver objetivamente problemas, as filosofias multiplicam respostas que se contrapóem, sem que ocorram superaçôes entendidas como mudanças que corrigem defeitos, preservando qualidades.

A incomunicabilidade entre as filosofias se torna manifesta quando nem nominalmente destacam - como é o caso, por exemplo, do existencialismo e da filosofia analítica - os mesmos problemas. E pouco atenua o quadro de enclausuramento metodológico e entrincheiramento conceitual estarem as filosofias nominalmente de acordo a respeito de que problemas merecem ser reputados fundamentais quando se enredam em insanáveis divergências sobre como enfrentá-los e sobre o que conta como uma genuína solução. Os impasses que perduram são evidência de que não há como comparar a competência das várias filosofias em solver problemas.

Até para saber se um problema é realmente comum a diferentes filosofias é necessário formular o problema em uma linguagem neutra; neutra em relação às linguagens ou teorias em que o problema é formulado. Se as teorias se sucedem sem que se registre um aumento na capacidade de solver (os mesmos) problemas, o único progresso possível é o de se buscar uma enunciação cada vez mais rigorosa dos problemas. Se a filosofia não resolve qualquer tipo de problema substantivo, a própria filosofia se transmutando em metafilosofia precisa se perguntar o que causa a impotência e se náo cabe renunciar a eles ou pelo menos se adstringir aos aspectos conceituais que envolvem. Não há 
como deixar de causar estranheza o fato de raras filosofias encararem como um problema para a filosofia o fato de o valor explicativo postulado por uma de suas escolas não ser reconhecido pelas alteridades. A criação de universos teóricos autossubsistentes é um exercício de pensamento puro capaz, quando muito, de vir a inspirar a formulação de conceitos aplicáveis à explicação real de conteúdos, mas não deságua em alguma forma de cognição.

Se cada filosofia propende a entrincheirar-se é porque, inexistindo progresso cumulativo em filosofia, pode acalentar a pretensão de justificar seu sistema explicativo com base em padróes epistêmicos próprios. Sem superar as endêmicas divergências acumuladas, cada nova filosofia apresenta suas construçôes teóricas como equivalendo à introdução de um novo "paradigma”. Propóe a instauração de uma forma nova de ver as coisas sem sequer se deixar nem indiretamente monitorar pelas coisas. E quando não se credencia a tanto, uma nova filosofia se diz nova, alegando ter competência para promover a eliminação de velhas questóes. O comum é cada filosofia se conceder o poder de prover a solução - ou dissolução - dos problemas já formulados e dos novos que introduz. Mas, no fundo, o que uma filosofia destaca em si mesma como revolucionário é, no essencial, fruto da adoção de diferentes pressuposiçóes absolutas.

Pouco atenua o "quadro da insolubilidade endêmica" propor, como faz Rorty (1999, p. 6), a leitura

[...] dos grandes filósofos do ocidente como terapêuticos em vez de construtivos, como nos dizendo que problemas não discutir: problemas escolásticos no caso de Descartes, problemas cartesianos no caso de Kant, problemas kantianos no caso de Hegel, e problemas metafísicos [...] nos casos de Nietzsche, James e Dewey.

Se a filosofia só serve para afastar problemas antes priorizados, chegará a um ponto em que não conseguirá mais promover substituiçóes. Se sua meta é eliminar problemas, a atividade de dissolvê-los poderá culminar na dissoluçáo de todos, com o consequente desaparecimento da própria filosofia. Sem uma agenda positiva, sem poder oferecer solução, apenas dissolução, para seus problemas recalcitrantes, a filosofia fica incapacitada de alcançar qualquer tipo de progresso. Com base na visão substitutivista, problemas que ficaram sem solução darão lugar a outros, que também ficarão sem solução. E se as teorias se multiplicam, gerando algaravia explicativa, nunca se sai, em termos cognitivos, do lugar. Problemas que se acumulam sem soluçáo fomentam 
conflitos teóricos que, por se arrastarem sem superação, não têm como desembocar em revolução.

Körner (1969, p. 20) afirma que "[...] em filosofia, como alhures, um problema é em geral completamente compreendido apenas quando uma solução é encontrada para ele com base em determinado método". Dessa visão se segue que os problemas filosóficos clássicos não são, por não se conhecer solução para eles, devidamente compreendidos. E enquanto não forem solvidos, terá a filosofia uma compreensão precária de seus problemas e, ipso facto, de sua própria natureza. E se os problemas da filosofia que se mantêm sem solução forem insolúveis, nunca a filosofia conhecerá bem a si mesma. Desconhecerá a si mesma por carecer do adequado entendimento de seus problemas.

Caso se concorde com Rorty (1994, p. 125) - "[...] não podemos considerar a verdade como a meta de uma investigação, já que o propósito é propiciar um acordo entre seres humanos sobre o que fazer, é criar um consenso sobre os fins a serem atingidos e os meios a serem usados para isso" - a capacidade retórica de persuadir se torna mais importante que a de prover justificação epistêmica. A filosofia passa a se voltar para a coordenação da ação e não para a compreensão da ação e do mundo em que se desenrola. A outra observação de Rorty - de que "[...] a investigação que não consegue coordenar o comportamento náo é uma investigação, mas um mero jogo de palavras" pode ser associada à visão de que o valor de uma teoria é medido por seu poder de formar consciências e plasmar condutas. A função latente, psicossocial, da filosofia pode até ser a de induzir padrôes comportamentais. Porém, colocar de lado a concepçáo tradicional de cognitividade náo faz desaparecer o desafio de justificar - contra as alternativas - as crenças em torno das quais o consenso é construído.

Diferentemente do panorama exibido pela filosofia, há base para se afirmar que o conhecimento científico tem resolvido problemas e promovido a superação de resultados. Justifica-se supor que algumas teorias foram justificadamente abandonadas e outras acolhidas porque se mostraram manifestamente superiores em termos explicativos e preditivos. Quanto ao progresso instrumental, quase ninguém ousa questionar os feitos da ciência. Newton-Smith (1984, p. 61) sublinha que, “[...] independentemente das controvérsias em torno da natureza do progresso científico, há uma concordância geral de que tem havido progresso no sentido mínimo do termo, no sentido instrumentalista”. E completa: “[...] tem havido enorme aumento 
no poder preditivo e manipulativo das teorias contemporâneas da física e da química em relação às teorias de trezentos anos atrás".

Os séculos de filosofia deixam claro que os avanços têm sido mais conceituais que substantivo-explicativos e mais internos às escolas que universalmente compartilhados. Os avanços confinados ao âmbito de cada escola não têm como ser reconhecidos como conquistas de todo um campo de conhecimento. Esse é um problema enfrentado não só pela filosofia como também pelas ciências humanas e sociais. Por elaborarem teorias insuscetíveis de confirmação ou refutação, as filosofias não se alimentam do que a "realidade" exibe e sim de cada uma indigitar falhas na(s) outra(s). Cada filosofia acredita que demonstra sua superioridade, apontando erros, nunca objetivamente comprovados, nas demais. As pronunciadas contraposiçóes entre filosofias se arrastam sem suscitar o esperado "desconforto" epistêmico por se supor que escolher de forma argumentada uma delas promove uma maior aproximaçáo à verdade. Desconsidera-se que, ao apresentar como resultado inovador o que foi obtido pela aplicaçáo de um método criado por ela mesma, ou por uma tradição específica de pensamento, uma filosofia deixa de poder ser universalmente avaliada. A controvérsia é endêmica, porque às recalcitrantes divergências substantivas e conceituais se reage com avaliaçóes baseadas em parâmetros instituídos por uma das teorias em pugna.

Rorty (1994, p. 121) pergunta: por que os problemas filosóficos são ao mesmo tempo tão intrigantes e tão estéreis? Por que os filósofos, tanto hoje quanto na velha Grécia, ainda estão mergulhados em debates sem chegar a uma conclusão, dando voltas dentro dos mesmos círculos dialéticos, sem jamais convencerem uns aos outros, mas ainda capazes de atrair discípulos? A inocuidade resolutiva da filosofia náo a faz perder o atrativo de, com suas teorias, abordar questôes instigantes que não admitem solução prática ou técnica. Se os principais problemas filosóficos formulados pelos pensadores gregos continuam essencialmente os mesmos é porque ainda não se encontrou solução para eles ou porque simplesmente são insolúveis. O que torna cognitivamente embaraçosa a situação da filosofia é não saber se está lidando com problemas sem solução ou se lhe tem faltado competência para resolvê-los. Existe ainda a possibilidade de a filosofia abrigar teorias que tenham conseguido dar um adequado encaminhamento, próximo de uma soluçáo, para alguns de seus problemas e ainda assim se revelar incapaz de objetivamente discriminar quais são. Pode, por exemplo, o empirismo (construtivo) contemporâneo oferecer as melhores respostas para a questáo de como se forma e valida o conhecimento 
sobre fatos, sem ter ele mesmo como provar isso e sem ser assim avaliado pela maioria dos filósofos.

O fato de a agenda filosófica pouco ter-se alterado ao longo do tempo eadem sed aliter - não seria desconcertante, se a pesquisa filosófica se destacasse por produzir um tipo de progresso - cumulativo - em que cada nova teoria de algum modo aprofunda ou alarga as antecessoras. E o fato de possuir uma história sem superações leva a filosofia a amalgamar passado e presente. Salienta Whitehead (1954, p. 294) que "[...] a filosofia, mais que qualquer ciência, é dominada por sua literatura passada”. É fácil constatar que a história da ciência desperta diminuto interesse, e mais de tipo sequencial-evolutivo, entre os praticantes das ciências maduras. A história da ciência é irreversível no sentido de que não se retomará, por exemplo, a teoria geocêntrica. Já a história da filosofia é considerada fundamental para se fazer filosofia. Há estudiosos que chegam a sustentar que fazer filosofia é, no essencial, reconstruir racionalmente sua história. Nenhuma outra disciplina confere tanta importância à sua história, nenhuma vê a história como vital para o que faz no presente. Isto em parte se explica por, em filosofia, nada ser superado, por inexistir em filosofia a destruição criativa que promove o abandono de uma teoria em prol de outra comprovadamente superior.

Destaca Russell (1977, p. 121-2) que "[...] a filosofia, diferentemente da ciência, não tem feito progresso visto que cada filósofo original tem de começar o trabalho de seu ponto zero, sem poder aceitar nada de definido na obra de seus predecessores". E, para piorar o quadro, salienta Russell que “[...] a maioria das filosofias tem sido construídas à maneira de blocos indivisos, de tal forma que se não são totalmente corretas são totalmente erradas e não podem ser usadas como base para investigações ulteriores”. Essa a razão por que cada filosofia desqualifica a outra e proclama fazer uma revolução. Podese afirmar que Ptolomeu erra, ao colocar a Terra no centro do universo, mas não que, por exemplo, Descartes comete um erro, ao conferir a Deus papel fundamental no sistema de justificaçôes epistêmicas proposto nas Méditations e Métaphysiques. Nas ciências maduras, as mudanças marcantes, as produtoras de grandes avanços, não apenas subvertem e derrubam teorias, como tambem acarretam o abandono de problemas.

Já se observou com propriedade que as questôes filosóficas são de um tipo que constitui erro técnico alegar tê-las resolvido e ingenuidade conceitual deixar de formulá-las. Só que formulá-las não basta. O ideal seria enfrentá-las com rigor metodológico, de modo a se oferecerem respostas 
comparáveis em termos de suas capacidades resolutivas. Como cada filosofia adota procedimentos metodológicos peculiares, deixa de poder ambicionar conferir universalidade a seus resultados. Mesmo quando exibem convergência interrogativa, as filosofias se diferenciam pela diminuta confluência responsiva.

Entendendo que "[...] um método é um modo de lidar com dados, com a evidência”, indaga Whitehead (1954, p. 287): a que evidências a filosofia apela? Criando teorias de máxima generalidade e empregando métodos generalistas que não precisam levar em conta a diversidade ontológica do que existe, a filosofia, sobretudo na versão metafísico-especulativa, não é impactada por qualquer tipo de evidência. Bloor (1991, p. 80) enfatiza o truísmo de que "[...] a filosofia, da forma como é correntemente concebida, não tem a mesma dinâmica que os estudos empíricos e históricos, já que nela inexistem entradas [inputs] controladas de novos dados". Essa constatação o leva a propor uma leitura sociológica dos conteúdos filosóficos: “[...] a crítica e a autocrítica em filosofia são simplesmente afirmaçôes dos valores e perspectivas de algum grupo social". O fato de existirem problemas cuja busca de solução não passa pela testagem de hipóteses ou pela realizaçáo de experimentos não os desqualifica nem os reduz a epifenômenos da vida social. Tampouco serve de justificativa para as propostas de enfrentá-los com base apenas no puro exercício da razão.

Campbell (1921, p. 27) defende a tese de que "[...] a ciência é o estudo dos juízos em torno dos quais se pode chegar à concordância universal”. Ziman (1974, p. 9) a repete: "[...] o objetivo da ciência é um consenso baseado na opinião racional sobre o mais amplo campo possível”. Já em filosofia, como observa Descartes (1957a, p. 17), “[...] nenhuma coisa há que não suscite disputa e que não seja, em conseqüência, duvidosa”. No mesmo tom de Descartes, Hume (1969, p. 41) declara: "[...] nada há que não se mostre objeto de discussão e sobre o qual os homens de saber não apresentem opiniōes contrárias". Em continuação, Hume arremata com diagnóstico ainda mais duro: "[...] princípios são adotados na base da confiança, conseqüências são deles deduzidas de modo defeituoso, há falta de coerência entre as partes e de evidência no todo, e tudo isso está espalhado pelos sistemas dos mais eminentes filósofos e tem levado desonra à filosofia”.

Por se manter praticamente no mesmo patamar de indecidibilidade epistêmica, a proliferação teórica torna imperioso discutir o valor cognitivo de cada filosofia e da filosofia como um todo. Se a filosofia não tem como promover a eliminação de erros que redunde em substituição de teorias, de piores por 
melhores, então não está apta a decretar obsolescências explicativas. Se quase tudo nela subsiste como insuperável confrontação, quase nada pode ser justificadamente afastado, já que tudo pode sempre ser retomado em outras bases. Por não se desvencilhar de conteúdos, por ter uma história da qual não se consegue extrair uma hierarquização objetiva das teorias em termos de seu valor explicativo, a filosofia não abriga as tantas revoluçôes que seus corifeus alardeiam.

Em comparação com o progresso cumulativo, lento e gradual, a derrubada de teorias universalmente aceitas tem o poder de promover os grandes saltos do conhecimento. Quanto maiores os avanços, mais se chocam com o que tinha alcançado elevado grau de confirmação. A comprovação de que as revoluçóes ensejam as mais importantes conquistas explicativas e a de que nenhuma pesquisa pode ser dada por concluída enquanto houver evidências a considerar valem para a ciência, mas não para a filosofia. A busca interminável em ciência, tão enfatizada por Weber (1952, p. 138), resulta de cada uma de suas conquistas equacionar alguns problemas criando ao mesmo tempo outros. $\mathrm{O}$ estoque total de quebra-cabeças nunca diminui. $\mathrm{O}$ comum é o surgimento de novos problemas a partir dos que foram solucionados. Sem falar que em ciência há sempre a possibilidade de novas e imprevistas ocorrências abalarem teorias consolidadas. Todavia, o acúmulo de problemas em ciência não resulta, como parece ser o caso em filosofia, de impotência explicativa. Se a filosofia é passível de ser questionada como empreendimento cognitivo não é por ser limitado seu poder de solucionar problemas, ou por tal poder ficar confinado à dimensão conceitual, e sim por sic et simpliciter não lograr resolvê-los.

É recorrente a tese de que o que se tem delimitado como campo próprio da filosofia se compóe de questóes às quais não se conseguiu ainda dispensar tratamento metodológico seguro como o utilizado pelas ciências. $\mathrm{Na}$ opiniáo de James (1956, p. 88), “[...] questôes respondidas de forma acurada passaram a ser chamadas de 'científicas' de tal forma que o que os homens chamam de filosofia nada mais é que o resíduo de questóes ainda sem resposta”. Russell (1952, p. 155) repete quase ipsis litteris a análise de James: “[...] as questóes capazes de receber respostas definidas passam a ser formuladas pelas ciências, enquanto que aquelas para as quais não se dispóe até o momento de resposta definida continuam a fazer parte do resíduo do que se chama filosofia”. Do fato de o conhecimento empírico vir se expandindo de modo espetacular nos últimos séculos não se segue que suas fronteiras avançarão a ponto de virem a abarcar todas as questóes que têm sido enfrentadas pela filosofia. Pelo menos 
os Lebensproblemen - Quem sou? O que devo fazer? Como devo viver? Como proceder para ser feliz? Que finalidade dou ao viver? - parecem fadados, como assinala Wittgenstein $(1971,6.52)$, a se manter impermeáveis aos métodos que têm sido empregados pelas ciências.

\section{A INCOMENSURABILIDAdE EM FILOSOFIA NÁO É FRUTO DE REVOLUÇÁO}

Os autores que detectam incomensurabilidade entre teorias científicas não a veem como generalizada. Só se manifestaria em momentos definidos, como quando uma teoria, tradição ou paradigma é substituído por outra pela ocorrência de uma revolução. Na filosofia, a incomensurabilidade é a tônica em razão de as teorias, independentemente de protagonizarem revoluçóes, não terem como submeter suas diferenças à arbitragem objetiva. Isso faz com que absolutizem o que as singulariza. Como as mais destacadas escolas filosóficas criam "sublinguagens" com o jargão filosófico, adotam modelos epistemológicos próprios e fazem inventários ontológicos idiossincrásicos, é inevitável que subsista incomensurabilidade entre suas teorias. Se a filosofia pretende chegar à verdade, qual de suas teorias a alcança e como reconhecê-la? A dificuldade, por Hegel (1955, p. 22) destacada, é que "[...] todas asseguram que são as verdadeiras apontando critérios distintos por meio dos quais se há de reconhecer a verdade".

O diálogo entre as filosofias já de saída fica prejudicado por usarem os mesmos termos com significados diferentes. Pouco ajuda fazer uso do mesmo vocabulário, quando até os significados dos termos-chave variam de uma filosofia para outra. Debalde haver concordância quanto aos problemas fundamentais a enfrentar, quando os modos de abordá-los e os modelos de equacionamento chegam a resultados incomensuráveis. Por se submeterem $a$ padrões próprios de avaliação, nenhuma das tantas teorias sobre o Ser, a finitude, a substância, a natureza da realidade, a imortalidade da alma, a existência de Deus etc. tem como se apresentar como tendo um maior conteúdo de verdade e um menor de falsidade. Em suma, como representando avanço explicativo objetivamente mensurável - na comparação com as outras.

Por resultarem principalmente da adoção de diferentes pressuposiçôes absolutas, as divergências entre as filosofias são de um tipo que inviabiliza comparações capazes de definirem méritos relativos. Inexistindo uma linguagem comum, por meio da qual duas filosofias podem ser completa e perfeitamente expressas, deixa de ser possível compará-las. São tâo grandes as dificuldades para 
tornar duas filosofias intertraduzíveis, para promover a expressão de ambas, de suas diferenças, em uma linguagem comum, que raramente se tenta levar a cabo tal empreitada. A desinteligência entre filosofias, entre seus conceitos-chave, se perpetua não em virtude de uma ordem teórica ter sido derrubada, ter dado lugar a outra assentada em pilares muito diferentes, e sim por cada filosofia abraçar variadas pressuposiçóes absolutas. As insuperáveis dissensões explicativas entre as filosofias voltadas para as questóes de primeira ordem não promanam de se interpor uma revolução entre elas, mas de não reconhecerem um mesmo solo de "evidências" como árbitro de suas diferenças, de não abordarem e problematizarem seus "objetos" adotando as mesmas pressuposiçóes absolutas.

Os critérios propostos para avaliar e comparar filosofias nunca granjeiam universalidade, por cada um estar afinado com as pressuposiçóes absolutas de uma das competidoras. Avanços definidos à luz de parâmetros estipulados por uma filosofia não são reconhecidos pelas demais. Para se constituir em autêntico empreendimento explicativo, para deixar de se confinar à análise conceitual, a filosofia tem de elaborar teorias julgáveis em termos de seus respectivos conteúdos de verdade e falsidade. A comparação das filosofias que elaboram teorias de primeira ordem não se mostra objetivamente realizável em razão de não se conseguir executar a tarefa preliminar de submeter a aferiçôes epistêmicas universais cada uma em separado. E, se não se consegue identificar o valor explicativo de cada uma, não há como definir qual a superior. É comum se qualificarem as filosofias de incompatíveis. Ocorre que é inapropriado tachar de incompatíveis sistemas de ideias que se mostram incomparáveis.

As dificuldades de comparar filosofias são negligenciadas por aqueles que acreditam que a simples "dialética dos contrários" propicia a escolha da melhor. O fato é que, quando se avolumam as discordâncias insubmissíveis a crivos epistêmicos neutros, náo há como deixar de supor que podem ter fonte e base puramente "linguísticas", sociais ou político-ideológicas. Nada impede que sejam propostas teses excludentes até nas disciplinas em que os dispositivos de avaliação metodológica são compartilhados. A diferença é que os conflitos entre elas não se mantêm indefinidamente no mesmo estado de inconclusividade. Pretendendo ser conhecimento, a filosofia não pode deixar de buscar avanços e superaçóes e de contar com sistemas de avaliação que permitam objetivamente identificá-los. Mas que tipo de progresso pode a filosofia fazer se suas escolas não conseguem entabular um efetivo intercâmbio crítico? Fica difícil falar de progresso, se não há escola filosófica que reconheça ter sido corrigida ou superada por outra. Cada filosofia ambiciona desqualificar 
e enterrar as predecessoras no passado. A razão disso é que diversas filosofias reivindicam a verdade e só uma pode ser verdadeira. Porém, como pode cada uma assegurar ser a verdadeira, sem ter como prová-lo e sem ter como demonstrar que as demais são falsas?

Como sublinha Granger (1989, p. 23), “[...] cada um dos grandes pensadores acreditou trazer progressos e, às vezes, até mesmo um progresso definitivo". O problema é que as contraposiçóes indefinidamente reiteradas, marcadas pela indecidibilidade lógico-empírica, mantêm estagnado o campo do saber que as abriga. Recorrer sem parcimônia, como faz a filosofia, à retórica da ruptura é uma forma de desviar a atenção da falta de progresso universalmente reconhecido. Mesmo importantes guinadas filosóficas, como o linguistic turn, representam mudanças circunscritas. Se as grandes mudanças conceituais e explicativas postuladas por um pensador não são assim vistas pelos demais, não afetam a filosofia como um todo.

$\mathrm{Na}$ falta de progresso cumulativo, é compreensível que as filosofias se apresentem como protagonistas de descontinuidades conceituais e/ ou explicativas. Mas sem progresso cumulativo e sem o posterior desmoronamento dos alicerces que o geravam e sustentavam não é apropriado qualificar as mudanças teóricas, ainda que significativas, de revolucionárias. As filosofias chamam de revoluçáo o que nada mais é que a adoção de outro modelo de abordagem associado a diferentes pressuposiçôes absolutas. A incomensurabilidade, as dificuldades semântico-epistêmicas de estabelecer comparações objetivas são ilusoriamente encaradas por elas como expressão de uma ruptura. Desobrigadas de demonstrar em que são objetivamente superiores, se dedicam a criar a ilusão de que estão fazendo uma revoluçáo. Sem uma forma de aferir se avanços são realmente feitos, deixa de ser possível hierarquizar o valor explicativo das várias filosofias. Se cada filosofia qualifica a si mesma de revolucionária, é porque se torna juíza de si mesma.

A ciência normal, como a descreve Kuhn, equivale à pesquisa firmemente baseada em realizaçôes científicas passadas que determinada comunidade cientifica reconhece durante algum tempo como supridora dos fundamentos das práticas posteriores. É sua derrocada que leva à revolução. Como não há filosofia normal, inexiste a ordem teórica estabelecida contra a qual um novo sistema de ideias é construído. Para que fosse revolucionária, uma filosofia precisaria destronar um modelo teórico amplamente aceito, propondo outro prontamente ou crescentemente endossável. Um sistema de ideias que se contrapóe a outros, sem lograr comprovar sua superioridade explicativa, nada 
contém de revolucionário. É necessário que exista a normalidade explicativa, resultante da vigência de um modelo teórico por muito tempo aceito, para que se possa contra ela (pretender) fazer uma revolução. Para que não sejam apenas nominais, as revoluçôes filosóficas precisam demonstrar ter a capacidade de resolver problemas até então sem solução ou de pelo menos solucionar novos problemas. Não configura revolução defender, como sói ocorrer em filosofia, o abandono de problemas antes priorizados em nome do enfrentamento de outros sem conseguir solver nem os velhos nem os novos.

Uma das principais causas da incomensurabilidade é o uso logicamente frouxo, gerador de confusóes conceituais, que as grandes teorias filosóficas fazem das línguas naturais. Dado o entrincheiramento linguístico e o enclausuramento metodológico ostentado pelas filosofias, critérios de aferição nunca chegam a ser cross-theory criteria, conforme os caracteriza Hesse (1980, p. xiv), nunca se mostram capazes de julgar as diferenças entre as teorias, sem adotar as pressuposiçóes absolutas de uma delas. Se, em filosofia, a incomensurabilidade se circunscrevesse a casos específicos em que uma explicação destrona outra, se concernisse a situaçóes e momentos específicos de sua história, seria fruto de mudanças teórico-conceituais que poderiam merecer ser qualificadas de revolucionárias. A incomensurabilidade não representa uma súbita e momentânea cessação de diálogo entre os filósofos, decorrente da introdução de um modelo explicativo em ruptura com o que vinha sendo aceito. Em filosofia, a precariedade do diálogo em torno de conceitos e, mais ainda, sobre conteúdos, é a tônica porque os encastelamentos linguísticos, os particularismos epistemológicos e as balcanizaçóes ontológicas impedem o estabelecimento de méritos relativos.

As variadas teorias metafísicas, ontológicas, éticas, estéticas, gnosiológicas etc. suscitam o desafio de como arbitrar suas diferenças, de modo a se poder optar justificadamente por uma delas. Não é apropriado qualificar todas de conhecimento (filosófico), tendo em vista que, em aspectos cruciais, se antagonizam e chegam ao ponto de defender teses que se excluem. Teses antinômicas, que sobrevivem sem se submeterem a arbitragem considerada legítima por todas, tornam contestável o valor cognitivo do domínio do saber que as acolhe. No caso de teorias que, a despeito de nominalmente se reportarem ao mesmo, versam sobre coisas diferentes, não há como justificadamente optar por uma delas. Não há como demonstrar que uma explica mais e melhor. Se as filosofias parecem ser sobre as mesmas coisas até quando não o são e parecem abordar coisas diferentes até quando só poderiam ser as mesmas, é porque suas 
teorias se compóem de proposiçóes com opacidade referencial. E isso as torna insuperavelmente incomensuráveis.

Subsistindo incomensurabilidade entre as diferentes tradições de pensamento, e não apenas entre as filosofias apartadas por uma revolução, a escolha de uma delas náo tem como ser justificada como representando avanço para a filosofia como um todo. Náo sendo possível identificar a teoria que tem maior conteúdo de verdade, menor de falsidade e maior capacidade resolutiva de problemas, não há como decretar de forma epistemicamente justificada que uma delas é superior a outra(s). A preferência por uma delas acaba sendo determinada pela influência de fatores extracognitivos genericamente rotuláveis de psicossociais. Os desencontros explicativos não ficariam enredados no impasse da incomensurabilidade endêmica, se as diferentes filosofias compartissem critérios de comparação que ensejassem aferir, por exemplo, quando se alcança uma maior aproximação à verdade.

Muito se tem discutido em que extensão as teorias científicas são subdeterminadas pelos fatos. As filosóficas são, na melhor das hipóteses, perifericamente afetadas por evidências empíricas. Essa é uma das razóes de por que as explicaçôes em filosofia proliferam. Como não faz descobertas de fatos, a filosofia se dedica à pura invenção teórica. Sendo tudo construção interpretativa, os avanços não ocorrem pelo acréscimo de novas informaçóes, nem pela derrubada de teorias contrariadas pela realidade. Quando fatos têm o poder apenas de subdeterminar teorias, quando respaldam igualmente diferentes teorias, várias explicaçóes podem emergir como empiricamente adequadas. A escolha de uma delas pode se dar com base em requisitos extracognitivos, mas não se pode alegar, como se pode em filosofia, que não é empiricamente sustentada. Se os fatos sequer subdeterminam as teorias e a exigência da consistência interna é por todas igualmente atendida, conforme ocorre em filosofia, não há inovação que possa ser reputada revolucionária.

A incomensurabilidade devida à variação radical de significado dos termos teóricos é a tônica em filosofia. Significados de termos-chave que variam ao sabor de contextos teóricos autocontidos produzem equivocidade. $\mathrm{O}$ que agrava a incomensurabilidade em filosofia é o fato de ela só ter linguagem teórica. As construçôes teóricas da filosofia sequer têm vínculos indiretos com uma linguagem observacional possuidora de termos que se referem a entidades observáveis. Sendo assim, a comparação entre filosofias só pode se dar em termos de suas linguagens teóricas. Contudo, sendo as linguagens que empregam autossubsistentes, imunes a qualquer monitoramento a elas 
extrínseco, fica inviabilizada a avaliação interteorética. Como tudo em filosofia é o tempo todo teórico, não há como fazer uma comparação, ainda que limitada, entre suas explicaçôes, tomando o extrateórico como crivo de avaliação. Hume (1952, p. 457) defende que "[...] quando nutrimos a suspeita de que um termo filosófico está sendo empregado sem nenhum significado ou idéia (o que é muito freqüiente) devemos apenas indagar: de que impressão é derivada essa suposta idéia?" Mas, caso se exija da filosofia que indique a matriz sensorial das ideias que elabora, quase nada nela sobreviverá. O mesmo vale para vários conceitos das ciências naturais e para muitos das ciências sociais e humanas.

Além de elaborarem explicações incomensuráveis, as filosofias propóem formas de vida, como as denomina Wittgenstein (1968, \$226), inconciliáveis. As diferentes visóes filosóficas de homem têm o potencial de afetar seus modos de (con)viver. A tese de que "o homem é lobo do homem", como propóe Hobbes, e a de que "o homem é naturalmente bom", como apregoa Rousseau, constituem antropologias filosóficas indutoras, independentemente de seu valor cognitivo, de "padrốes comportamentais". O mesmo pode ser dito da visão de Aristóteles (1952b, p. 446) de que "[...] o homem é por natureza um animal político (zoon politikon)". E da de Rousseau (1981, p. 85), que propala que caso se pense nos homens provenientes da natureza e aí dispersos, não se conseguirá conceber como puderam renunciar à sua liberdade inicial e deixar a vida natural para adotarem sem qualquer necessidade a escravatura e as misérias da ordem social. Por mais que uma das teses se mostre mais plausível, não se pode decretar a falsidade da outra. Visóes excludentes que se mantêm impermeáveis à arbitragem objetiva acabam favorecendo escolhas ideológicas e/ou axiológicas.

Muito mais que na ciência, na filosofia é difícil estabelecer uma rígida separaçáo entre contexto da descoberta e contexto da justificação. Apesar disso, um texto filosófico pode ser perfeitamente entendido e reconstruído sem se levar em conta as variáveis contextuais que contribuíram para sua formação. Podem-se compreender as críticas de Platão à democracia, sem subordiná-las à classe social a que pertencia. Ocorre, porém, que se a confirmação crescente de uma teoria, ou a superioridade explicativa sobre as alternativas, não tiver como ser estabelecida será menos justificável desvinculá-la do solo em que brotou. Se fosse possível nas filosofias distinguir de modo nítido verdade e gênese, justificação e descoberta, ficaria mais fácil rechaçar a tentação sociológica de reduzi-las a construçóes sociais ou ideologias políticas. 


\section{EXISTE A FILOSOFIA OU SÓ FILOSOFIAS?}

O progresso representado pelo alargamento ou aprofundamento do que já se sabia - como, por exemplo, o perseguido por Aristóteles (1948, livro I), quando aborda a problemática das causas - só esporadicamente está presente na filosofia. Isso leva cada filosofia a priorizar o estabelecimento de diferenças com as outras, a perseguir descontinuidades e rupturas, em detrimento da correção de falhas ou insuficiências específicas. Por carecer de uma história marcada pela lapidação de resultados e acréscimos explicativos, cada filosofia se diz revolucionária, alardeando desnudar erros nas teorias rivais, mas sem lograr demonstrar que dispóe de meio eficientes de corrigi-los ou eliminá-los. A despeito da insistência na retórica da revolução, nunca se demonstra que um filósofo refuta outro.

O tipo endêmico de incomensurabilidade que se instaura entre filosofias dá azo à prevalência da retórica da ruptura com base na qual todas se consideram desobrigadas de enfrentar o desafio de fazer comparaçóes objetivas, com o fito de estabelecer seus respectivos valores explicativos. Sem a obrigação de provar que são realmente erros o que critica nas alteridades pode uma filosofia rejeitá-las em bloco, chegando ao extremo de desqualificar toda a filosofia precedente. Por não serem fruto de teorias com maior conteúdo de verdade, menor de falsidade e maior capacidade explicativa, as tantas teorias revolucionárias postuladas pelos filósofos sequer conseguem demonstrar que são superiores às antecessoras. A retórica da revolução ajuda a ocultar o fato de que uma teoria filosófica é incapaz de demonstrar objetivamente como e em que vai além das outras.

As pronunciadas e diuturnas contraposiçóes provocam a especiosa impressão de que a revolução é mais frequente na filosofia que na ciência. Mas, diferentemente das grandes mudanças explicativas ou conceituais, a multiplicação de antagonismos em filosofia não provoca destronamentos e entronizaçóes. Para que houvesse mudança de "paradigma”, reversão gestáltica, em filosofia, seria necessário que uma teoria se tornasse amplamente aceita em virtude de as outras terem deixado de suportar o crivo das críticas e terem sido abandonadas em respeito à superioridade explicativa da nova. Entretanto, não é isso que ocorre. O que se costuma chamar de revolução em filosofia não equivale à derrubada de uma teoria, durante algum tempo tida como modelar na solução de problemas, e a hegemonização de outra. Ademais, deixa de se justificar falar de revolução, se cada filosofia que alega fazer uma revolução adota uma concepção singular de filosofia. 
Duas teorias físicas, ainda que separadas por uma revolução, aderem a uma mesma concepção de física e por isso é adequado que se vejam pertencendo a uma e mesma ciência. Se, por um lado, não faz sentido pensar que cada nova filosofia faz uma revolução, por outro, é questionável que as diversas filosofias, propondo diferentes concepçóes de filosofia, pertençam a um só e mesmo tronco cognitivo. Quando se apoiam em excludentes pressuposiçôes absolutas que inviabilizam o intercâmbio crítico entre elas, as filosofias podem formalmente fazer parte de um mesmo domínio do saber. Mas estáo irremediavelmente apartadas, por não perseguirem o mesmo tipo de explicação, e até de conhecimento, com base nos mesmos procedimentos e pressupostos. Embora brotando do mesmo solo, as filosofias são árvores de espécies diferentes, com frutos, resultados explicativos, incomparáveis. Formam um quadro muito diferente do desenhado por Descartes (1957b, p. 87), em que a filosofia desponta unificada e unificadora: “[...] toda a filosofia é uma árvore cujas raízes são a metafísica, o tronco a física e os galhos que saem desse tronco são todas as outras ciências".

As contraposiçóes explicativas se tornam improfícuas, quando por séculos se mostram insuperáveis as dificuldades que impedem sua superação. Exemplo de dura competição na corrida pela elaboração de um modelo adequado de explicaçáo é o estado em que se encontrava a Óptica, antes de Newton. Kuhn (1970, p. 74-5) observa que "[...] nenhum período entre a Antigüidade remota e o fim do século XVII exibiu uma única concepção da natureza da luz universalmente aceita”. Havia um bom número de escolas e subescolas em competição, de sorte que cada uma extraía forças de sua relação com alguma metafísica. Cada uma destacava como fornecedora de observaçóes cruciais o conjunto particular de fenômenos ópticos que sua própria teoria poderia explicar melhor. Até Newton, nenhuma teoria granjeara aceitação geral. Os pesquisadores não dissentiam apenas com relação às suposiçôes teóricas fundamentais, mas também acerca dos tipos de fenômenos observacionais relevantes para sua teoria. Newton extraiu o primeiro paradigma quase que uniformemente aceito na Óptica Física. Nenhum processo marcado pelo acúmulo de divergências teve em filosofia desfecho parecido.

Antes de Newton, a física não obtinha êxito no enfrentamento do desafio de superar as diferentes opções teórico-experienciais que se mantinham como roteiros de investigação incomunicantes. Segundo Kuhn, quando uma ciência supera o estádio de permanente disputa entre escolas, tem início sua idade madura. Superada a luta intestina entre correntes, alcançada a 
unificação, daí em diante toda pesquisa passa a ser feita sob a batuta de um paradigma. A força unificadora do paradigma permite-lhe estatuir os padróes de trabalho legítimo no âmbito da ciência que rege. Não há em filosofia tradiçôes consolidadas de pesquisa que se assemelhem ao paradigma científico e ao processo revolucionário que leva a seu destronamento. E, se nela não há Newtons, é porque a disputa se arrasta sem superaçóes e sem unificaçôes.

Nenhuma revolução tem como ocorrer quando as Escolas se multiplicam, sem que o modelo explicativo de uma delas chegue se impor às demais. Duradouros consensos, como os que se formaram a partir da mecânica clássica, resultaram da superação da fragmentação e dispersão explicativas. E se, na física, ocorre o desmoronamento de um consenso a ponto de irromper uma revolução, não demora até que um novo acordo geral se forme. Por mais profundas que sejam as mudanças sofridas pelas ciências maduras, nunca são (pensadas como) refundaçóes, recomeços em novas bases. Como cada filosofia pretende ser a filosofia, precisa se apresentar em "ruptura" com as demais, mesmo sem fazer nenhuma revolução. Emparedadas pela diaphonia - pela interminável e indecidível contraposição de explicaçóes e visões - as filosofias encontram na retórica da revolução uma saída artificial.

Para se aferir se uma teoria representa efetivamente avanço explicativo, é necessário submetê-la a processos de rigorosa comparação semânticometodológica com as precedentes. Por não ter como fazer isso, a filosofia trivializa a noção de revolução. Por serem internas a cada escola, as inovaçóes conceituais ou explicativas náo são incorporadas pela filosofia como um todo. Quando universais, as contribuiçóes dadas por uma filosofia concernem a modos de pensar e não a teses substantivas. As histórias da filosofia tornam patente a incomensurabilidade entre filosofias, ao fracassarem em determinar, com base em parâmetros objetivos, de que modo um pensamento representa progresso em relação a outro(s). Para que a filosofia conseguisse de modo justificado apresentar, fazendo um balanço crítico de sua história, uma de suas teorias como superior, precisaria provar que tal teoria alcança verdades sobre tópicos sobre os quais as outras defendem teses falsas. As indecidíveis contraposiçôes explicam por que não causa estranheza um filósofo hoje se declarar aristotélico, como ocorreria se um físico adotasse uma concepção de luz anterior à de Newton.

Não há revoluçôes em filosofia se entendidas como transformações teórico-explicativas em que o novo modelo soluciona não só velhos e recalcitrantes problemas, mas também novos. E não há, se delas se exigir 
que promovam mudanças que desemboquem em novidades explicativas e, principalmente, em rupturas, sem deixarem de preservar as conquistas anteriores. Para que revoluçôes ocorressem em filosofia, seria indispensável o tipo de crítica que se mostra capaz de detectar possíveis dissonâncias das teorias com a "realidade". Como as teorias filosóficas não têm falsificadores potenciais, não são contrastáveis com a experiência, não ocorrem refutaçôes que provoquem grandes mudanças explicativas. Diferentemente do que se pretende em filosofia, grandes mudanças explicativas não fazem tabula rasa das conquistas anteriores. Revoluçōes envolvendo conteúdos, e não apenas conceitos, implicam não apenas eliminação de defeitos, mas também conservação de feitos.

Sendo os critérios medidores da qualidade argumentativa e do valor explicativo internos a cada corrente filosófica, é inevitável que uma filosofia procure se justificar, atribuindo ao que tem de peculiar o poder de ter um acesso privilegiado ao que o real tem de essencial. Observa Whitehead (1954, p. 287) que [...] "a filosofia tem sido acometida pela falácia dogmática, isto é, pela crença de que os princípios de suas hipóteses de trabalho são claros, óbvios e irreformáveis". Instala-se a incomensurabilidade entre as filosofias, por cada uma tomar como claro e óbvio o que outras assim não veem e por cada uma considerar irreformável seu núcleo duro. Enquanto em ciência as dificuldades de intercâmbio crítico entre os pesquisadores tendem a se restringir aos períodos das grandes mudanças que culminam na troca de um paradigma por outro, em filosofia são permanentes.

Como exemplifica Ayer (1984, p. 2), o historiador da física pode mostrar como o sistema ptolomaico de astronomia foi suplantado no século XV pelo sistema heliocêntrico de Copérnico e como este último levou ao desenvolvimento, um século depois, das teorias de Kepler e Galileu. E como essas teorias foram aprimoradas e incorporadas na mecânica clássica de Newton e como os princípios de Newton entraram em conflito, no século XIX, com a teoria eletromagnética de Clerk Maxwell, baseada nas descobertas de Faraday, e como o conflito foi resolvido nas teorias de Einstein da relatividade. Arremata Ayer: “[...] por mais revolucionária que a nova teoria possa ser, por mais que represente uma ruptura, como é o caso da teoria quântica, com conceitos estabelecidos, ganha aceitaçáo geral quando logra provar seu valor como ferramenta de explicação e predição".

Nada de parecido acontece em filosofia, em virtude de nela as inovaçôes não decretarem obsolescências explicativas. À diferença das conversóes que 
se verificam depois das revoluçóes científicas, em filosofia não se formam consensos que, uma vez derrubados, são substituídos por outros. Visto que novos modos de ver náo abalam os fundamentos dos preexistentes, o que se tem é a multiplicação de esquemas explicativos e conceituais que se pretendem rupturistas, sem promoverem superaçôes. Por isso, até o mais remoto sistema especulativo pode ser sempre retomado, sem que isso gere a impressão de resgate de algo anacrônico. Pode alguém, por exemplo, endossar o platonismo epistemológico sem dar a mínima para as críticas de Aristóteles ao Mundo das Ideias. $\mathrm{O}$ antagonismo entre as correntes filosóficas subsiste indefinidamente, em virtude de nenhuma delas ter respaldo na ordem das coisas para decretar a anacronia explicativa das demais. É um escândalo para a filosofia que até hoje realismo, construtivismo e idealismo se antagonizem, sem que se possa, por exemplo, determinar qual deles apreende (melhor) o papel dos modos de ver do sujeito e dos modos de ser do objeto no processo de produção do conhecimento.

A proliferação sem seleção, a multiplicação de visôes sem hierarquização epistêmica do valor explicativo de cada uma, torna inevitável questionar a filosofia substantiva como empreendimento cognitivo. Porém, sem deixar de reconhecer as tantas conquistas conceituais da filosofia. E também o papel fundamental dos experimentos mentais no enfrentamento de problemas que não têm como ser equacionados, levando-se apenas em conta o que mostram os fatos.

OLIVA, Alberto. The incommensurability between philosophies and the inexistence of revolutions in philosophy. Trans/Form/Ação, Marília, v. 35, n. 2, p. 199-238, Maio/ Ago., 2012.

\begin{abstract}
This article deals with metaphilosophical issues. In it we will discuss the reasons that lead philosophy, unlike science, to evaluate itself in terms of its capacity to attain cognitive aims. In particular, we will seek to identify how and why philosophy becomes an issue for itself. With the exception of the social sciences in which one can find critical studies of the type sociology of sociology, science in general does not put itself into question. Rare are the cases where science comes to the extreme of questioning its own cognitivity. Philosophy in some of its most lucid and useful exercises does not avoid assessing its own cognitive powers. In the context of such metaphilosophical concerns, our article intends to question the pretensions of the great philosophies to making revolutions. We will defend the thesis that the revolutions claimed by philosophers do not occur. Aside from this, we will stress that the incommensurability subsisting among philosophies is not caused by conceptual or explanatory ruptures, but by the adoption of different absolute presuppositions, as defined by Collingwood.
\end{abstract}

KEYWORDS: Essentialism. Epistemic justification. Incommensurability. Cumulative progress. Revolution. 


\section{REFERÊNCIAS}

ALTHUSSER, L. Positions. Paris: Éditions Sociales, 1976.

ARISTÓTELES. On Interpretation. Trad de E. M. Edghill. In: Aristotle. Vol. I. Londres/ Chicago: Encyclopedia Britannica, 1952a.

ARISTÓTELES. Politics. Trad de Benjamin Jowett. In: Aristotle. Vol. II. Londres/Chicago: Encyclopedia Britannica, 1952b.

ARISTÓTELES. La Métaphysique. Trad. de J. Tricot. Paris: J. Vrin, 1948.

AUSTIN, J. Philosophical Papers. Nova Iorque: Oxford University Press, 1970.

AYER, A. J. Philosophy in the Twentieth Century. Nova Iorque: The Vintage Books, 1984.

BLOOR, D. Knowledge and Social Imagery. Londres: Routledge and Kegan Paul, 1991.

BRADLEY, F. Appearance and Reality. Londres: Elibron Classics, 2005.

CAMPBELL, N. What is Science? Londres: Methuen \& Co, 1921.

CARNAP, R. The Logical Syntax of Language. Trad. de Amethe Smeaton. Londres: Kegan Paul, 1937.

COLLINGWOOD, R. An Essay on Metaphysics. Oxford: Clarendon Press, 2007.

DESCARTES, R. Méditations Métaphysiques. Paris: Librairie Larousse, 1950.

DESCARTES, R. Discours de la Méthode. In: Oeuvres de Descartes. Paris: Librairie J. Gilbert, 1957a.

DESCARTES, R. Les Principes de la Philosophie. In: Oeuvres de Descartes. Paris: Librairie J. Gilbert, 1957b.

DUMMETT, M. Origins of Analytical Philosophy. Cambridge: Harvard University Press, 1993.

DUMMETT, M. The nature and Future of Philosophy. Nova Iorque: Columbia University Press, 2010.

GRANGER, G. Por um Conhecimento Filosófico. Trad de Constança M. César e Lucy M. César. Campinas: Papirus, 1989.

HEGEL, G. W. E. Lecciones sobre la Historia de la Filosofia. Trad. de Wenceslao Roces. Mexico: Fondo de Cultura Económica, 1955.

HEIDEGGER, M. Introduction to Metaphysics. Trad de Gregory Fried e Richard Polty. New Haven:Yale University Press, 2000.

HESSE, M. Revolutions and Reconstructions in the Philosophy of Science. Bloomington: Indiana University Press, 1980. 
HUME, D. An Enquiry concerning Human Understanding. Chicago/Londres: Encyclopedia Britannica, 1952.

HUME, D. Treatise of Human Nature. Londres: Penguin Books, 1969.

JAMES, W. Some Problems of Philosophy. In: Selected Papers on Philosophy. Londres: J. M. Dent, 1956.

KANT, I. The Critique of Pure Reason. Trad de J. M. D. Meiklejohn. Chicago/Londres: Encyclopedia Britannica, 1952.

KÖRNER, S. Fundamental Questions in Philosophy. Middlesex: Penguin Books, 1969.

KUHN, T. The Structure of Scientific Revolutions. In: Foundations of the Unity of Science. Vol. II. Chicago: The University of Chicago Press, 1970.

LOCKE, J. An Essay concerning Human Understanding. Londres/Chicago: Encyclopedia Britannica, 1952.

MARX, K. Capital: A Critique of Political Economy. Livro III. Trad. de David Fernbach. Londres: Penguin Books, 1991.

MILL, J. S. Auguste Comte and Positivism. Cirencester: The Echo Library, 2005.

MOORE, G. The Philosophy of G E Moore. Editado por P. A. Schilp. Nova Iorque: Tudor Publishing, 1952.

NEWTON-SMITH, W. The Role of Interests in Science. In: GRIFFITHS, A. P. (Org.). Philosophy and Practice. Londres: Cambridge University Press, 1984.

PIAGET, J. Sagesse et Illusions de la Philosophie. Paris: Presses Universitaires de France, 1968.

POPPER, K. The Logic of Scientific Discovery. Londres: Hutchinson, 1972.

POPPER, K. The Demarcation between Science and Metaphysics. In: The Philosophy of Rudolf Carnap. Illinois: The Open Court Publishing, 1978.

QUINE, W. V. Epistemology Naturalized. In: Ontological Relativity \& Others Essays. Nova Iorque: Columbia University Press, 1969.

REICHENBACH, H. The Rise of Scientific Philosophy. University of California Press, 1954.

RORTY, R. Relativismo: Encontrar e Fabricar. In: CÍCERO, A.; SALOMÃO, W. (Org.). O Relativismo enquanto Visão do Mundo. Rio de Janeiro: Francisco Alves, 1994.

RORTY, R. Truth and Progress: Philosophical Papers. Vol. 3. Cambridge: Cambridge University Press, 1999.

ROUSSEAU, J. J. Discours sur L'origine et les Fondements de L'inegalité parmi les Hommes. Paris: Editions Fernand Nathan, 1981.

RUSSELL, B. The Problems of Philosophy. Nova Iorque: Oxford University Press, 1952. 
RUSSELL, B. The Wisdom of the West. Nova Iorque: Doubleday Co., 1959.

RUSSELL, B. Misticismo e Lógica. Trad. de Alberto Oliva e L. A. Cerqueira. Rio de Janeiro. Zahar, 1977.

SOKAL, A.; BRICMONT, J. Imposturas Intelectuais. O Abuso da Ciência pelos Filósofos Pós-modernos. Trad de Max Altman. Rio de Janeiro: Record, 1999.

WARNOCK, G. Criticism of Metaphysics. In: PEARS, D. (Org.). The Nature of Metaphysics. Londres: Macmillan \& Co., 1957.

WEBER, M. Science as a Vocation. In: GERTH, H. H.; WRIGHT MILLS, C. (Org.). From Max Weber. Essays in Sociology. Londres: Routledge and Kegan Paul, 1952.

WHITEHEAD, A. Adventures of Ideas. Nova Iorque: The Macmillan Company, 1954.

WILLIAMSON, T. The Philosophy of Philosophy. Malden: Blackwell Publishing, 2007.

WITTGENSTEIN, L. Philosophical Investigations. Trad de G. E. M. Anscombe. Nova Iorque: The Macmillan Company, 1968.

WITTGENSTEIN, L. Tractatus Logico-Philosophicus. Edição bilíngue com a versão inglesa de C. K. Ogden. Londres: Routledge and Kegan Paul, 1971.

ZIMAN, J. Public Knowledge. The Social Dimension of Science. Londres: Cambridge University Press, 1974.

Recebido em: 04.05.2011

Aceito em: 27.10.2011 